https://doi.org/10.22210/suvlin.2020.090.06

\title{
Arbanaški na raskrižju. Vitalitet i održivost jednog manjinskog jezika, Lucija Šimičić i Klara Bilić Meštrić. Srednja Europa, Zagreb, 2018.
}

\section{Općenito o knjizi}

Predmet je ovog prikaza knjiga Arbanaški na raskrižju: vitalitet i održivost jednog manjinskog jezika autorica Lucije Šimičić i Klare Bilić Meštrić. Objavljena je u rujnu 2018. godine kod izdavača Srednja Europa te predstavlja sintezu rezultata dobivenih u sklopu projekta dviju autorica Promicanje višejezičnosti u Zadru: etnojezični vitalitet Arbanasa (ProViZa). Projekt se odvijao tijekom 2015. i 2016. godine na Sveučilištu u Zadru uz financijsku potporu Europskog socijalnog fonda. Knjiga se teorijski se oslanja na ranije radove i promišljanja dviju autorica (Šimičić 2011; Bilić Meštrić 2014 idr.).

Knjiga se sastoji od predgovora, sedam poglavlja, popisa literature te kazala pojmova. U nastavku ću nešto više reći o predmetu knjige, temeljnim pojmovima i metodološkom okviru, a nakon toga ću pobliže prikazati svako od sedam poglavlja.

\section{Predmet knjige}

Predmet su ove knjige zajednica zadarskih Arbanasa i njihov jezik, arbanaški. Prema autoricama interes za Arbanase kao zajednicu proizlazi iz njihova kompleksnog i dinamičnog identiteta, o čemu govore na više mjesta u knjizi, a ovdje možemo navesti jedno od tih mjesta (str. 28):

Arbanasi u simboličkom, društvenom i prostornom smislu predstavljaju primjer pluralnosti, kompleksnosti i promjenjivosti društvenih, političkih, ali i jezičnih identiteta te bi bilo pogrešno analizirati ih kao zajednicu s jasno određenim granicama, što je bio uobičajen pristup u ranijim analizama odnosa jezika i zajednice. Taj je odnos uglavnom dinamičan i obuhvaća čitav repertoar identiteta (...).

Kompleksnost arbanaškog identiteta i okolnosti u kojima se razvijao i u kojima danas djeluje pokazali su se jedinstvenima, zbog čega u dostupnoj literaturi nije bilo moguće pronaći adekvatan teorijsko-metodološki model koji bi mogao poslužiti za cjelovit opis arbanaške zajednice. Iz tog razloga autorice za potrebe svojeg istraživanja preuzimaju elemente različitih modela i pristupa, pri čemu se ponajprije oslanjaju na one modele i pristupe koji na identitet i vezane pojmove gledaju kao na dinamične i fluidne pojavnosti.

Istraživanje predstavljeno u knjizi autorice određuju kao »svojevrstan polifonijski prikaz različitih diskursa koji sudjeluju u konstrukciji i percepciji arbanaškog identiteta (...)« (str. 44). Kao osnovne ciljeve istraživanja navode sljedeće (str. 57 - 58): 
Oslanjajući se na najnovije spoznaje u području istraživanja etnojezičnog vitaliteta, ovim smo istraživanjem željele utvrditi sociolingvističko stanje zadarske arbanaške zajednice te stavove i identifikacijske procese kao bitne psihosocijalne činitelje etnojezične održivosti.

Sam arbanaški jezik, tj. njegov ustroj (fonologija, gramatika i leksik), nije predmetom ove knjige, već se knjiga ponajprije bavi stavovima pripadnika arbanaške zajednice prema tom jeziku i važnosti koju pridaju tom jeziku u određivanju svojeg arbanaškog identiteta (usp. str. X). Drugim riječima, u knjizi se analiza identiteta prvenstveno zanima za pitanje koje je mjesto arbanaškog jezika u arbanaškom identitetu.

U knjizi se arbanaški naziva jezikom, što je svjesna odluka dviju autorica (str. 9, usp. pogl. 5), iako je arbanaški u tradicionalnom dijalektološkom smislu govor koji pripada gegijskom dijalektu albanskog jezika. I sami Arbanasi o arbanaškom često govore kao o govoru, a ne jeziku (ibid., usp. str. 107ff.). Ovdje je svakako važno napomenuti da arbanaški jezik za mnoge pripadnike zajednice nije stvarna svakodnevna kategorija jer velika većina njih jezik ne govori, a često i ne razumije (usp. str. 70 - 79) te je kao takav na rubu izumiranja, odnosno prema UNESCO-voj ljestvici kategoriziran kao »ozbiljno ugrožen « (str. 11). U knjizi se ističe da su za današnju ugroženost arbanaškog ključne bile 60-te i 70-te godine 20. stoljeća, kada dolazi do prekida međugeneracijskog prenošenja jezika i kada mnogi Arbanasi odlučuju da sa svojom djecom više neće govoriti arbanaški (str. 75). Prema toj pozadini knjiga uz pitanja o arbanaškom identitetu razmatra i pitanja koliko je arbanaški uopće aktivno prisutan u zajednici (tj. njegov vitalitet) te je li arbanaški uopće moguće spasiti od izumiranja (tj. njegovu održivost).

\section{O metodologiji predstavljenog istraživanja}

S obzirom na to da je jasno formulirani cilj knjige "analizirati konstruiranje etnojezičnog identiteta u javnom, političkom, znanstvenom i osobnom diskursu samih članova zajednice« (str.12), razumljivo je da je metodološki gledano središnji postupak ovog istraživanja kvalitativno terensko istraživanje, odnosno prikupljanje podataka od samih pripadnika zajednice. Da bi uopće mogle među pripadnicima zajednice prikupiti specifični tip informacija potreban za ovakvo istraživanje, autoricama je bilo nužno »dublje ući u zajednicu « jer je tek tada "moguće steći uvid u slojevitost stavova, identifikacijskih procesa, ideologija i odnosa moći koji određuju njezin vitalitet i održivost (str. 58). Svoju metodu autorice nazivaju višedimenzionalnom (str. 13), pri čemu se razmatraju i subjektivni i objektivni čimbenici koji određuju etnojezični vitalitet. Ipak, u istraživanju su temeljni primarni podatci prikupljeni od pripadnika arbanaške zajednice kroz osamnaest individualnih intervjua, dvije fokusne grupe te sudjelovanje u nizu aktivnosti koje su se odvijale unutar arbanaške zajednice (str. 13). U takvim kontekstima ispitanici su često imali priliku dublje potkrijepiti i objasniti svoje stavove prema svojem identitetu i jeziku. 
Tako prikupljeni podatci dopunjeni su spoznajama iz različitih sekundarnih izvora. Svoje istraživanje autorice smještaju u paradigmu tzv. istraživanja uz sudjelovanje (engl. participatory research), koji »zagovara ujednačenu raspodjelu odgovornosti između istraživača i sudionikâ istraživanja te teži aktivnom uključivanju sudionikâ u sam istraživački proces« (str. 15). Takav pristup suprotstavljen je paradigmama koje teže da etnojezični vitalitet odrede na temelju objektivnih podataka prikupljenih s pomoću kvantitativnog metodološkog pristupa. Za takav pristup autorice smatraju da nije primjenjiv na zajednicu kakva je arbanaška, gdje postoji nepodudaranje između jezičnog i etničkog identiteta (str. 15 -16).

\section{Komu je namijenjena ova knjiga}

Autorice nedvosmisleno određuju svoj pristup kao »odgovornu lingvistiku«, pod kojom se podrazumijeva »aktivno promišljanje jezične raznolikosti, ne isključivo zbog njezine vrijednosti kao kulturne baštine ili kao izvora znanstvenih spoznaja, već zbog značenja koje svaki od jezika koji je sačinjavaju ima za svoje govornike« (usp. pogl. 1), pri čemu se ističe »ključna, makar i ograničena« uloga lingvista »u osvještavanju jezičnih stavova i mogućnosti da se neki jezika očuva, odnosno revitalizira« (str. IX). U tom smislu ova je knjiga namijenjena i pripadnicima arbanaške zajednice, »ili barem onom dijelu zajednice koji arbanaški osjeća kao dio vlastitog identiteta« (str. 12) te kao takva može poslužiti kao osnova za buduće strategije očuvanja arbanaškog jezika (ibid.). Istovremeno, ona otvara prostor glasovima pripadnika zajednice te u knjizi na puno mjesta čitatelj dobiva priliku za uvid u izravne navode pripadnika zajednice. Toje u skladu s gore iznesenom postavkom o važnosti ravnopravnog sudjelovanja sudionika istraživanja, odnosno viđenjem da oni »ovdje nisu pasivni informanti čija je jedina uloga biti izvorom podataka istraživačicama, već su aktivni sudionici koji su sami oblikovali smjer istraživanja te sudjelovali $\mathrm{u}$ interpretaciji podataka kroz stalan dijalog « s istraživačicama i drugim sudionicima istraživanja (str. 17). Stoga knjiga ne samo da je namijenjena pripadnicima zajednice, već su je oni na neki način i oblikovali i ona stoga nosi i njihov potpis. Zaključno, istraživanje predstavljeno u knjizi »se ne provodi samo na zajednici, već i sa zajednicom i za zajednicu« (str. 18).

\section{Prikaz po poglavljima}

Poglavlja u knjizi, uz iznimku prvog i drugog poglavlja, imaju relativno uniformnu strukturu. Prvo se razmatra opći teorijski okvir i uvode ključni pojmovi, a zatim se na temelju tako postavljenog okvira analizira situacija specifično u arbanaškoj zajednici. Ta je analiza redovito praćena brojim izravnim navodima prikupljenima od samih pripadnika zajednice. Svako poglavlje zaokružuje zaključak koji sažima trenutačno poglavlje te ga povezuje sa sljedećim. 
U prvom poglavlju Uvod: jezična raznolikost i metajezični režimi autorice najprije daju prikaz različitih načina na koje se prikazuje i obrađuje jezična raznolikost i njezina ugroženost (tzv. metadiskursi). Prema autoricama ti se metadiskursi mogu podijeliti u dvije široke skupine, od kojih se u prvoj o ugroženim jezicima govori slično kao što se govori o ugroženim biološkim vrstama te ih se promatra kao bogatstvo ljudskog roda, dok se u drugoj naglasak stavlja na zastupanje samih govornika jezika te se ugrožene jezike predstavlja kao nešto što valja štititi zbog njihovih govornika - drugim riječima, oni »ne tretiraju jezike kao zasebne organizme ili vrste, već im je namjera zastupati interese samih govornika « (str. 2). Autorice napominju da se u knjizi žele "pozicionirati između tih dvaju ideološki suprotstavljenih polova«, što tumače na sljedeći način: »nastojat ćemo se odgovorno postaviti prema jeziku i govornicima ne romantizirajući pritom ulogu lingvista koji rade u manjinskim kontekstima, a istovremeno ćemo zauzeti kritički stav prema znanstvenom diskursu o jezičnoj ugroženosti misleći pritom na ulogu i značenje koje jezik ima za istraživanu zajednicu« (str. 6). U nastavku istog poglavlja kritički se raspravlja o pojmu jezika i njegovoj primjenjivosti na arbanaški te se pritom ističe važnost sociolingvističke dimenzije u definiranju jezika, što autorice u konačnici i navodi da arbanaški nazovu jezikom (usp. gore). O ovom se problemu dalje raspravlja u petom poglavlju. Prvo poglavlje završava pregled sadržaja knjige.

$\mathrm{U}$ drugom poglavlju Kontekst istraživanja arbanaške zajednice raspravlja se o metodologiji istraživanja, o čemu je već bilo riječi ranije. U trećem poglavlju Jezik i zajednica, jezik u zajednici, na neki način najvažnijem za razumijevanje istraživanja provedenog u knjizi, raspravlja se o odnosu jezika i identiteta općenito te na primjeru arbanaške zajednice. U poglavlju se definira pojam jezične zajednice te se razmatra odnos jezika i identiteta s ciljem da se utvrdi po kojim obilježjima Arbanase možemo smatrati zasebnom zajednicom. Problematizira se uloga jezika u definiranju zajednice uz napomenu da se jezik promatra vrlo partikularno, odnosno on je za autorice »uvijek povijesan, lokalan, specifičan oblik djelovanja, posve određenih vremenskih i prostornih koordinata (str. 19). Polazišna je pretpostavka da je svaki identitet, pa tako i jezični, hibridan i fluidan, zbog čega ljude u načelu nije moguće svrstati u homogene skupine po različitim obilježjima (str. 21). Daje se podjela na tri razdoblja odnosno paradigme proučavanja jezika i identiteta: strukturalistički ili varijacijski, kvalitativni etnološki i poststrukturalistički. Autorice se u istraživanju oslanjaju na kvalitativni etnološki pristup, koji se odlikuje odmakom »od statičnog gledanja na identitet kao unaprijed zadanu društvenu kategoriju koja se zrcali $\mathrm{u}$ jeziku« te prepoznavanjem »dinamične prirode odnosa jezika i identiteta (str. 22) te osobito na poststrukturalistički, u kojem se jezik i identitet smatraju neodvojivima, a subjektu se pristupa kao »decentriranom, fragmentiranom, kontradiktornom i nedovršenom « (str. 23).

Ostatak poglavlja posvećen je analizi arbanaške zajednice i pitanju »kako se pripada arbanaškoj zajednici i što samim Arbanasima znači biti Arbanas« (str. 27). Prvo se razmatra odnos arbanaškog jezika i arbanaškog identiteta u vidu činjenice 
da većina pripadnika arbanaške zajednice tim jezikom ne govori, već im je materinski jezik hrvatski. Preuzima se koncept zajednice emocija, prema kojem arbanašku zajednicu definira veza s arbanaškim jezikom, ali ne kroz stvarnu jezičnu kompetenciju (većina Arbanasa ne govori jezik, a mnogiga ni ne razumiju), većkroz emotivni stav prema tom jeziku i afektivnu vezu s njime. Drugim riječima, mnoge Arbanase definira identifikacija s arbanaškim jezikom bez obzira na nedostatak jezične kompetencije. Ipak, za mnoge Arbanase jezik nije važan, a kamoli središnji identifikacijski element (usp. i str. 27, 28). Autorice stoga u ostatku trećega poglavlja detaljno analiziraju elemente (osim jezika) na kojima počivaju identitetski obrasci u arbanaškoj zajednici na temelju literature i provedenih intervjua. U ovom se dijelu teksta prvi puta u većoj mjeri citiraju navodi samih pripadnika arbanaške zajednice. Prepoznaju se tri ključna elementa u konstrukciji arbanaškog identiteta: priča o doseljenju, prezime i mjesto stanovanja. Prvi se odnosi na zajedničko povijesno iskustvo doseljenja u Zadar u 18. stoljeću, drugi na to da se s arbanaškim identitetom povezuju točno određena prezimena (na str. 32 - 33 daje se i njihov popis), a treći da arbanaški identitet često proizlazi iz stanovanja u zadarskoj četvrti Arbanasi.

Četvrto poglavlje Očuvanje i održivost arbanaškog podijeljeno je u dvije glavne cjeline. U prvoj cjelini (Što utječe na očuvanje jezika) daje se okvir unutar kojeg se mogu analizirati faktori koji utječu na jezični vitalitet te zamjenu i izumiranje jezika. U drugoj se cjelini (Arbanaški na raskrižju) neki od tih faktora analiziraju na primjeru arbanaške zajednice. Prva cjelina primjerice obrađuje pojmove zamjene jezika i jezične smrti. U kontekstu jezične smrti autorice prikazuju pristup koji je razvio njemački lingvist H.-J. Sasse, u kojem se povezuju tri skupine čimbenika koji dovode od izumiranja jezika, odnosno jezične smrti (vanjske okolnosti, jezično ponašanje i jezično-strukturne promjene). U tome važnu ulogu igraju vanjske okolnosti, a posebice situacija u kojoj većinski jezik počinje preuzimati od manjinskoga sve veći broj domena uporabe (obično onih formalnijih), što neizbježno dovodi do stigmatizacije manjinskog jezika. Nakon prikaza jezične smrti autorice tumače pojam etnojezičnog vitaliteta, koji se definira kao »teorijski koncept« koji je »rezultat pokušaja da se jednim okvirom objasni mnoštvo različitih čimbenika koji mogu uzrokovati gubitak etnojezičnog identiteta i zamjenu jezika u manjinskim zajednicama« (str. 50). Daje se detaljni kritički pregled različitih pristupa koji pokušavaju mjeriti etnojezični vitalitet kroz uvjetno rečeno objektivne pokazatelje (npr. broj i dob govornika). Takvi su se modeli pokazali manjkavima jer često ne mogu predvidjeti hoće li doći do izumiranja jezika niti ne mogu objasniti razlike u stavovima među pripadnicima iste etnojezične zajednice. Zato se uz objektivne pokazatelje u procjeni vitalnosti moraju uzimati u obzir i subjektivni faktori, odnosno percepcija i stavovi govornika, a dvije skupine pokazatelja ne moraju se nužno poklapati (str. 53). Mjerenje etnojezičnog vitaliteta ima za svrhu postizanje etnojezične održivosti. U tom smislu autorice ističu da je etnojezični vitalitet podređen pojmu etnoje- 
zične održivosti, a uz vitalitet na održivost utječu i snaga etnojezične zajednice te okolinski čimbenici (str. 55).

Kritika se nastavlja na početku druge cjeline poglavlja, gdje se uz prednosti koncepata etnojezičnog vitaliteta i održivosti kritički ističe i njihova pomalo esencijalistička ${ }^{1}$ narav, zbog čega se u istraživanju primjenjuje i etnografska metoda. Time se zaokružuje opis teorijskog okvira istraživanja te se u nastavku opisuju razni elementi s pomoću kojih možemo lakše razumjeti današnji etnojezični status arbanaškog. Jedan od njih je višejezičnost Arbanasa, koja obilježava zajednicu od njezinih samih početaka (str. 59 - 60 uz dodatnu raspravu na str. 93 - 96). Pri tome je važno istaknuti da je između jezika kojima su govorili Arbanasi uvijek postojala razlika u prestižu te je arbanaški uvijek bio percipiran kao podređen hrvatskom i zaratinskom (zadarskoj varijanti mletačkog). Uz ovo, u poglavlju se detaljno analizira institucionalni status arbanaškog, prvo iz perspektive međunarodnih mehanizama zaštite manjinskih i ugroženih jezika, a zatim i iz perspektive institucionalne zaštite jezika u Republici Hrvatskoj. U potonjem se odjeljku posebno ističe da je kod nas vrlo ukorijenjena ideja o Hrvatskoj kao jezično homogenoj zemlji, što naravno ne odgovara stvarnosti na terenu. Odjeljak završava zaključkom o arbanaškom kao nevidljivom jeziku (str. 69), budući da je riječ o jeziku »bez (mogućnosti) pravnog statusa«, koji »nije pokriven nikakvim oblikom podrške« (ibid.), uz iznimku priznavanja statusa nematerijalne kulturne baštine Republike Hrvatske 2010. godine.

Ostatak poglavlja posvećen je jezičnim praksama Arbanasa, gdje se vrlo opširno opisuje mjesto arbanaškog u arbanaškoj zajednici. Na ovome mjestu neću ulaziti u detaljniji prikaz svega što je navedeno u ovom dijelu četvrtog poglavlja jer on donosi veliko obilje iznimno zanimljivih podataka i uvida. Dat ću samo kratki pregled ovog dijela poglavlja, gdje autorice na temelju iskaza i svjedočenja samih pripadnika zajednice te sekundarne literature obrađuju problem broja govornika arbanaškog, zatim govore o mjestu arbanaškog u obrazovanju i njegovu mjestu u obitelji, kao i problemu međugeneracijskog prenošenja arbanaškog te uporabi arbanaškog u crkvi i u sklopu kulturnih događanja. Poglavlje završava analizom komunikacijskih niša u kojima uporaba arbanaški pokazuje osobitu otpornost te raspravom o ulozi višejezičnosti kao okidača procesa zamjene jezika, pri čemu autorice dolaze do zaključka da sama višejezičnost, budući da je karakteristična za Arbanase od njihova doseljenja, nije mogla biti okidačem zamjene jezika koja se događa u posljednjih nekoliko desetljeća.

Peto poglavlje Jezične ideologije i jezični stavovi u arbanaškom kontekstu analizira stavove Arbanasa prema jeziku i zajednici, pri čemu se autorice posebice zanimaju za ideologije koje se mogu iščitati iz tih stavova. Među njima je posebno izražena ideologija standardnog jezika. Interes za ideologije proizlazi iz uvida »da su jezična ponašanja i promišljanja o jeziku dijalektično povezana s dominantnim ideološkim

1 Esencijalizam je pojam iz antropologije i etnologije, odnosno "pretpostavka da neka skupina ili kategorija ima najmanje jedno ključno obilježje koje bitno određuje identitet svih njezinih pripadnika« (prema Struna - hrvatsko strukovno nazivlje, dostupno na http://struna.ihjj.hr/, pristup 26. listopada 2020.). 
obrascima“ (str. 103). U uvodu poglavlja autorice kritički raspravljaju o različitim definicijama i viđenjima ideologije, kao i slabostima tog pojma ističući pritom njegovu korisnost bez obzira na njegovo specifično shvaćanje kod pojedinih autora.

Nastavak poglavlja posvećen je analizi manifestacija različitih ideologija u kontekstu arbanaškog jezika i arbanaške zajednice te stavova o temama ključnim za razmatranje mogućnosti revitalizacije i održivosti arbanaškog (o tome se detaljnije govori u šestom poglavlju). U ovome se poglavlju tako raspravljaju ideologije koje stoje u pozadini viđenja da arbanaški nije jezik, već govor. Rasprava se nastavlja na četvrto poglavlje, gdje je pokazano kako je arbanaški uvijek bio dio vrlo kompleksnog heteroglosičnog konteksta od čak pet varijeteta (arbanaški, čakavski hrvatski, standardni hrvatski, zaratinski, standardni talijanski, str. 110), što je rezultiralo jezičnim kontaktom visokog intenziteta te velikim utjecajem ostalih varijeteta na arbanaški, posebice na leksičkoj razini. Iz toga proizlazi percepcija nekih Arbanasa o arbanaškom kao nekom obliku »jezične mješavine« (str. 109), odnosno »hibrida (str. 114 -115), u čemu se prepoznaje ideologija monoglosije. Raspravlja se i o odnosu arbanaškog i albanskog, odnosno pogledu prisutnom primarno među lingvistima, gdje se arbanaški promatra kao albanski dijalekt. Pritom autorice posebno ističu tri stoljeća samostalnog razvoja arbanaškog, zbog čega arbanaški zasigurno danas zaslužuje da ga se smatra "zasebnim jezičnim kodom « (str. 112). Kao što je već ranije istaknuto, autorice svjesno o arbanaškom govore kao o jeziku, a svjesne su i težine koju nosi takva odluka (str. 113):

» (...) u ovom radu o arbanaškom govorimo kao o jeziku kako bismo njegovom legitimizacijom u kontekstu ove knjige doprinijele promicanju materijalnih i diskurzivnih posljedica koje takvo imenovanje nosi.»

Osim inojezičnih utjecaja pri delegitimizaciji arbanaškog kao jezika prizivaju se ijoš neki faktori, od kojih autorice posebnu pozornost pridaju negativnoj percepciji jezične varijabilnosti i promjene. Osim toga raspravlja se i o ortografiji i zapisivanju arbanaškog te se ističe da arbanaški nema pisane tradicije, što ga isto tako u očima nekih delegitimizira kao jezik. Posebno je zanimljiva sljedeća rasprava, posvećena ideologiji jezične ispravnosti, prema kojoj postoji samo jedna ispravna verzija dotičnog jezika. Zanimljivo je primijetiti da se ona javlja i u nekodificiranim verzijama jezika bez pravopisne norme (str. 123). Ova je ideologija posebno štetna za ugrožene jezike jer dovodi do jezične nesigurnosti kod preostalih govornika, a osobito kod manje fluentnih govornika, polugovornika i onih koji jezik tek uče te obeshrabruje govorenje jezika. Time se ugroženi jezik dodatno destabilizira, što se može pokazati i na konkretnom slučaju arbanaškog, gdje jezična nesigurnost posredno utječe na sve manji interes za njegovo govorenje (str. 126).

Nakon rasprave o ideologijama koje su implicitno prisutne u percepcijama arbanaškog, u poglavlju se u njegovu drugom dijelu obrađuju specifični stavovi govornika, koje se tumači kao "most između jezičnih ideologija i jezične prakse« (str. 127). Kao posebna zanimljivost ističe se da su stavovi općenito dobri prediktori po- 
našanja, ali da se nerijetko susreće situacija u kojoj stavovi pojedinca i njegovo ponašanje nisu usklađeni, što autorice pokazuju i kroz analizu jezičnih stavova među Arbanasima. Ističe se i ključna uloga nejezičnih činjenica u oblikovanju jezičnih stavova, primjerice nizak društveni status govornika nekog jezika može se odraziti u negativnom stavu prema vlastitom jeziku. Prema se tome jezični stavovi pokazuju kao ključni u očuvanju i revitalizaciji jezika, odnosno uspjeh tih procesa ovisi o pozitivnim jezičnim stavovima, a u slučaju negativnih jezičnih stavova takvi su procesi osuđeni na neminovan neuspjeh (str. 128). Ipak, u slučaju arbanaške zajednice autorice opisuju paradoksalnu situaciju u kojoj pozitivni jezični stavovi prema arbanaškom nemaju pozitivnog učinka na bolje poznavanje ili češću uporabu jezika (str. 129). Autorice u nastavku poglavlju detaljno analiziraju tipove stavova prema arbanaškom jeziku ponovno polazeći od iskaza samih Arbanasa. Između ostalog analiziraju se konteksti uz koje se vežu pozitivni i negativni jezični stavovi, postojanje stigmatizacije govornika arbanaškog u ranijim razdobljima te stavovi prema očuvanju arbanaškog, za koje se kaže da su »usko povezani, ali ne uvijek i podudarni, sa stavovima prema arbanaškom kao jeziku« (str. 140).

U šestom poglavlju Mogućnosti očuvanja arbanaškog, ujedno i posljednjem prije zaključka, raspravlja se o faktorima koji nam omogućuju što objektivniju procjenu mogućnosti očuvanja arbanaškog, kao i o konkretnim koracima koje bi se trebalo poduzeti radi postizanja tog cilja. Poglavlje se oslanja na pojmove jezičnog planiranja i jezične politike te na analizu različitih skala za procjenu sociolingvističkog statusa nekog jezika. Jezičnom planiranju i jezičnoj politici posvećen je prvi dio poglavlja, u kojem se daju vrlo koristan pregledi usporedba različitih pristupa. Na ovaj se pregled nastavlja također vrlo koristan kritički pregled četiriju skala namijenjenih procjeni sociolingvističkog statusa jezika i jezične vitalnosti, na temelju kojih se daje i procjena za arbanaški (str. 162).

Iz te perspektive pristupa se raspravi o mogućnostima očuvanja arbanaškog. Osnovna je premisa poglavlja da očuvanje jezika neće imati uspjeha osim ako to jezična zajednica eksplicitno ne želi. Drugim riječima, očuvanje jezika ne može poteći izvana tj. odozgo (samo zato što to lingvist ili netko drugi smatra važnim), već isključivo iznutra, odnosno odozdo. Stoga se autorice u nastavku poglavlja oslanjaju na dijalog sa sudionicima istraživanja kako bi došle »do odgovora o mogućem i poželjnom smjeru postupanja u kontekstu arbanaškog“ (str. 166). Glavni izvor podataka za ovaj dio istraživanja prikupljen je na radionici s pripadnicima arbanaške zajednice održanoj u travnju 2016. godine, a dio je prikupljen u ranijem dijelu istraživanja (kroz intervjue i sl.). Radionica se pokazala korisnom i nužnom jer je omogućila dotad izostalu javnu raspravu među pripadnicima zajednice te razmjenu često oprečnih mišljenja i vizija o budućnosti arbanaškog. Analiza se oslanja osim na teorijski uvod iz ovog poglavlja i na prethodna poglavlja u kojima su analizirani elementi relevantni za procjenu održivosti jezika. Svi su oni relevantni za zaokruženu procjenu održivosti i mogućnosti očuvanja arbanaškog. Ovaj dio poglavlja stoga na temelju tako prikupljenih podataka i uvida analizira tri razine jezične održivo- 
sti: održivost identifikacije s jezikom (tj. »prihvaćenosti ideje o jeziku kao sredstvu identifikacije«, str. 168), održivost jezika kao sredstva komunikacije te uloga obrazovanja i pismenosti u postizanju održivosti jezika. Opstanak jezika kao sredstva identifikacije nužan je preduvjet za ostalo dvoje. Analiza potvrđuje već ranije spomenutu emotivnu vrijednost arbanaškog, odnosno visoku razinu identifikacije s jezikom, ali primarno kod starijih govornika. Mlađi pripadnici zajednice pak identifikaciju s arbanaškim identitetom sve manje vezuju uz jezik, a više uz druge elemente spomenute u trećem poglavlju (osobito mjesto stanovanja te podrijetlo). Arbanasi su itekako svjesni važnosti očuvanja arbanaškog kao jezika komunikacije, ali ne postoji jedinstven stav o tome kako to postići. Za to je relevantna rasprava o poduci arbanaškog, odnosno ima li smisla arbanaški poučavati u školi, ili možda kroz neki tečaj. Pokazuje se da su pripadnici zajednice prilično svjesni važnosti poduke jezika u njegovu očuvanju, ali su mnogi vrlo skeptični oko toga može li se kroz tečajeve i slične aktivnosti proizvesti govornike arbanaškog. Postojanje poduke dovodi u prvi plan potrebu za izradom udžbenika za učenje arbanaškog, što pak otvara još jedno sporno pitanje u zajednici - pitanje zapisivanja i ortografije, koje još uvijek nije riješeno (ortografija temeljena na hrvatskom pravopisu nasuprot onoj temeljenoj na albanskom). Uz to povlači se pitanje i jezične kodifikacije (standardizacije) i modernizacije (Haugenova elaboracija), a jedno od spornih pitanja jest izvor posuđivanja leksika za koji ne postoji ekvivalent u arbanaškom (hrvatski/talijanski nasuprot albanskom). S tim u vezi autorice ističu da prerano normiranje predstavlja potencijalnu prijetnju održivosti ugroženog jezika te je uputno taj korak odgoditi dok se ne uspostavi jezična održivost. Analiza u ovom dijelu poglavlja otkriva podijeljenu zajednicu, u kojoj postoje vrlo različite vizije o budućnosti arbanaškog i u kojoj se očituje nedostatak konsenzusa oko nekih ključnih pitanja (poduka jezika, ortografija, normiranje).

U zaključku poglavlja uz sažetak nalaza analize autorice ističu (str. 188 - 189) da je u kontekstu arbanaškog došlo do prekida međugeneracijskog prenošenja jezika te da se održivost jezika više ne može postići poticanjem govorenja arbanaškog u krugu obitelji te da su potrebni novi oblici revitalizacije.

Na kraju knjige nalazi se sedmo, zaključno, poglavlje Krajilinovipočetak:jezična raznolikost kao problem, resurs ili odgovornost?, koje zaokružuje knjigu kratkim pregledom ključnih ideja i sažetkom glavnih rezultata istraživanja predstavljenog u knjizi. Ističe se da se arbanaški u ovom trenutku suočava s prijelomnim trenutkom koji će odrediti njegov opstanak s obzirom na to da još postoje fluentni govornici, ali da je većina njih prešla šezdesetu. Stoga će budućnost arbanaškog odrediti generacija sadašnjih roditelja. Isto tako, o arbanaškome većinom postoje vrlo pozitivni stavovi, ali oni ostaju tek na deklarativnoj razini, što će se morati promijeniti ako se želi osigurati opstanak i dugoročna održivost arbanaškog. 


\section{Zaključno}

Prikazana knjiga pruža jedinstven i autentičan uvid u arbanašku zajednicu. Ona omogućuje čitatelju da stekne sliku o arbanaškom identitetu u svoj njegovoj, da posudim izraze iz knjige, decentriranosti, fragmentiranosti, kontradiktornosti i nedovršenosti. To je moguće upravo iz razloga što su autorice za potrebe svojeg istraživanja ušle u arbanašku zajednicu te su u knjizi sliku arbanaške zajednice oslikale ne samo kroz vlastitu analizu i vlastitim riječima, nego i kroz brojne navode samih Arbanasa. Isto tako, knjiga daje iscrpan i pouzdan prikaz različitih objektivnih okolnosti u kojima se danas nalazi arbanaški jezik te racionalno razmatra mogućnosti očuvanja i dugoročne održivosti arbanaškog.

Ova je knjiga važna u našem lokalnom kontekstu zbog duboko ukorijenjene ideje o jezičnoj homogenosti Hrvatske. Ona jasno pokazuje da je u našoj zemlji prisutna višejezičnost, ali da je često neprepoznata. Ona nas podsjeća da oko nas, a često i u našoj neposrednoj okoline postoje intrigantne zajednice i pojedinci s kompleksnim etnojezičnim identitetima. Ovo se istraživanje pridružuje sve većem broju sociolingvističkih i antropoloških istraživanja posvećenih različitim manjinskim varijetetima u Hrvatskoj, od kojih su mnoga pobrojana u popisu literature.

Ona je zanimljiva i u širem, međunarodnom kontekstu zbog u knjizi više puta isticane jedinstvenosti arbanaške situacije, na kakvu se u načelu ne može naići u postojećoj literaturi. Stoga se nadamo da će istraživanje predstavljeno u ovoj knjizi imati odjeka i u inozemnoj sociolingvistici i antropologiji zbog jedinstvenosti zajednice koju opisuje, ali i zbog inovativnog pristupa etnojezičnim zajednicama koji je razvijen upravo s ciljem adekvatnog opisa arbanaške zajednice.

\section{Citirana literatura}

Bilić Meštrić, Klara. 2014. Jezična raznolikost i jezične politike grada Osijeka. Doktorska disertacija. Sveučilište Josipa Jurja Strossmayera u Osijeku, Filozofski fakultet.

Šimičić, Lucija. 2011. Identifikacijski procesi ijezične promjene na otoku Visu. Doktorska disertacija. Sveučilište u Zagrebu, Filozofski fakultet.

Jurica Polančec 